Szwat-Gyłybowa, G. (2017). Zamurowana niewiasta, Odyseusz i Bułgarska Wielkanoc. Tonczo Żeczew w poszukiwaniu mitu konserwatywnego. Slavia Meridionalis, 17. https://doi. org/10.11649/sm.1368

\title{
Grażyna Szwat-Gyłybowa
}

Instytut Slawistyki

Polskiej Akademii Nauk

\section{Zamurowana niewiasta, Odyseusz i Bułgarska Wielkanoc. Tonczo Żeczew w poszukiwaniu mitu konserwatywnego ${ }^{1}$}

Choć w bułgarszczyźnie pojęcie konserwatyzmu weszło w życie w latach sześćdziesiątych XIX wieku, a więc czterdzieści lat po tym, jak wprowadził je do języka polityki i publicystyki François-René de Chateaubriand (1768-1848), od początku wraz z innymi pojęciami związanymi z modernizacją współtworzyło pewien szum informacyjny. „Konserwatyzm” był bowiem w XIX wieku konceptem pozbawionym na gruncie bułgarskim zaplecza kulturowego, politycznego i społecznego, porównywalnego w jakikolwiek sposób z tym na Zachodzie Europy czy w Rosji. Inspiracje światopoglądowe, napływające z zewnątrz przepuszczane były bowiem przez filtr rzeczywistości osmańskiej, która odgrywała rolę korektora. Poglądy ówczesnych quasi-konserwatystów

1 Artykuł powstał w ramach projektu badawczego pt. „Idee wędrowne na słowiańskich Bałkanach (XVIII-XX w.)" sfinansowanego ze środków Narodowego Centrum Nauki, nr projektu 2014/13/B/HS2/01057.

This work was supported by a grant from National Science Centre in Poland (decision No. 2014/13/B/HS2/01057). Competing interests: the author is a member of the Editorial Team of this journal.

Publisher: Institute of Slavic Studies, Polish Academy of Sciences.

This is an Open Access article distributed under the terms of the Creative Commons Attribution 3.0 PL License (creativecommons.org/licenses/by/3.0/pl/), which permits redistribution, commercial and non-commercial, provided that the article is properly cited. (c) The Author(s) 2017. 
sprowadzały się, mówiąc w największym uproszczeniu, do potępienia rewolucji jako narzędzia zmian, popierania umiarkowanych reform politycznych epoki Tanzimatu oraz propagowania edukacji i bułgarskiego ruchu oświatowego. Najczęściej zapośredniczone przez Greków, Serbów czy Turków wpływy myśli europejskiej, amerykańskiej czy rosyjskiej miały ograniczony zasięg społeczny. $\mathrm{W}$ atmosferze reform $\mathrm{w}$ imperium osmańskim specyficznie rozumiany konserwatyzm ewolucyjny stopniowo stawał się dla Bułgarów projektem takiej przebudowy państwa osmańskiego, z którym wiązane były nadzieje na lepsze warunki rozwoju i upodmiotowienie narodu. Poparcie dla wprowadzanych przez Wysoką Portę zmian w sposób pośredni czyniło z bułgarskich działaczy lojalistów i tradycjonalistów, ale jednocześnie także progresistów i okcydentalistów (Мишкова, 2005). Poza obszarem osmańskim taki konglomerat wartości mógłby dziwić.

I tak, na przykład szereg wątpliwości pojawia się przy próbie zaklasyfikowania takiego zjawiska jak walka Bułgarów o niezależną Cerkiew narodową (w latach 1860-1870), której celem było wyrwanie się spod wpływu innych poddanych sułtana - Greków, w owym czasie już posiadających własne państwo, ogarniętych swą Wielką Ideą i wykorzystujących Cerkiew do walki politycznej w Imperium (Китромилидис, 1999). Dotąd wtopieni w sterowany właśnie przez Greków millet $^{2}$ chrześcijański Bułgarzy szukali w walce o autonomię Cerkwi drogi do uzyskania takiej politycznej reprezentacji, która byłaby oparta na podstawach prawnych i obyczajowych Imperium. Z czasem, wraz z rozwojem tureckiej idei narodowej i osłabieniem osmanizmu jako koncepcji państwa wielonarodowego (Везенков, 2013) polityczne oczekiwania pierwszej fali działaczy bułgarskich (tzw. starych) okazały się już anachroniczne i większe wpływy zaczęło zdobywać rewolucyjnie nastawione, emigracyjne środowisko „młodych”. I chociaż wzajemne powiązania aż do wyzwolenia w 1878 roku pozostawały faktem, w roku 1869 rozgorzał konflikt, który upublicznił rysujące się w latach sześćdziesiątych coraz wyraźniej różnice postaw. Otóż na okoliczność odbywającej się w Paryżu międzynarodowej konferencji poświęconej sytuacji na Krecie zwolennicy projektu bułgarskiej autonomii w ramach imperium tureckiego opracowali trzy broszury propagujące ich punkt widzenia (Якимов, 2003). Jedna z nich, zatytułowana Прошението на българските нотабли до Конферениията в Париж wywołała wzburzenie części działaczy emigracyjnych z powodu nazwania się

2 Poddani sułtana zorganizowani byli w definiowane konfesyjnie millety, zarządzane według odrębnych praw. 
przez autorów „bułgarskimi notablami” (Николов-Зиков, 2011). Iwan Kasabow oskarżył ich o przypisanie sobie tytułu szlacheckiego i ośmieszył, rozwijając teorię narodu bułgarskiego jako w pełni egalitarnego: „Нам би било много жалко, ако би свободомислящий и демократический свет помислил само, че в наший българский народ има аристократическа зган, това би било една голема увреда за цял болгарский народ. Наший народ е съвсем чист от този вид сътворения “(Николов-Зиков, 2011, s. 203). Spór o słowa upublicznił tendencje egalitarne, które były jednym z czynników wiodących do osłabienia w owym czasie „konserwatywnego” projektu politycznego. I chociaż Cerkiew narodowa zdobyła w 1870 roku autonomię, zwycięstwo to nie zostało przez Bułgarów skonsumowane. Stworzona instytucja nie cieszyła się od momentu swego powstania prestiżem wystarczającym, by odgrywać rolę liczącego się gracza politycznego. Co prawda w odrodzonej Bułgarii partia konserwatywna, skupiająca dawnych „starych”, odegrała istotną rolę państwotwórczą, jednak projekt prawicowy nie zdołał się w tym kraju w pełni rozwinąć, co ilustruje zarówno meandryczna, kapryśna historia (oscylującej wokół neopogańskiej mistyki) myśli konserwatywnej w okresie międzywojennym (Еленков, 1998), jak i próby jej ukrytej rewitalizacji w epoce komunizmu. Ukrytej, gdyż propaganda komunistyczna skierowana była w owym czasie przeciwko dwóm ideologicznym wrogom wewnętrznym - religii i „faszyzmowi”, a dostęp do przedwojennego dziedzictwa intelektualnego był ściśle reglamentowany. Nie wznawiano tekstów wielu pisarzy tego okresu, a biblioteki nie udostępniały czytelnikom ich wcześniejszych publikacji.

W leksykografii okresu żiwkowskiego, leksem „konserwatyzm” interpretowano jako zacofanie, skłonność do zachowywania ustalonego porządku w życiu, wrogość wobec tego co nowe, postępowe. Partią konserwatywną nazywano taką partię, która „broni interesów burżuazji i kapitalistów” (Речник, 1976, s. 365). Współczesnym czytelnikom, niezaznajomionym ze specyfiką komunistycznej nowomowy, dziwny może się wydawać fakt, iż pomimo płaskiej stratyfikacji społecznej Bułgarów, historiografia doby Bułgarskiej Republiki Ludowej (dalej $\mathrm{BRL}$ ) wypracowała strategie mówienia o narodowej przeszłości w kategoriach klasowych. Dotyczyło to także kwestii walki Bułgarów o niezależną Cerkiew narodową w latach 1860-1970. Potrzeby ideologii narodowej doby komunizmu sprawiały, że walka o uniezależnienia się Bułgarów od Patriarchatu w Konstantynopolu (Carogrodzie/Stambule) w podręcznikach akademickich tego okresu interpretowana była w kategoriach konieczności historycznej jako obligatoryjny w teleologicznym porządku (i odwzorowujący europejską reformację) etap 
walki ludu o samostanowienie (Даскалов, 2002). Z reguły bowiem historiografia marksistowska stawała po stronie ruchu rewolucyjnego (tzw. młodych), rugając „ewolucjonistów” (tzw. starych) za ich konserwatywny, „burżuazyjny” światopogląd. Paradoks polega jednak na tym, że epoka żiwkowowska przyniosła również zwrot ku wartościom tradycyjnym.

W ślad za tendencjami w ZSRR I Sekretarz Bułgarskiej Partii Komunistycznej Todor Żiwkow w 1967 roku w przemówieniu „Kultura narodowa, kultura socjalistyczna" wskazał dawną tradycję kulturową Bułgarów jako jeden z konstytutywnych elementów współczesnej kultury (obok budownictwa socjalistycznego, kultury radzieckiej i postępowej kultury światowej). Otworzyło to drogę powrotu do rodzimej archaiki w jej najróżniejszych formach: od kultu historii narodowej począwszy (pisarstwo m.in. Antona Donczewa, Wery Mutafczijewej), przez pietyzm wobec ludowej mistyki (np. twórczość Wasiła Popowa), po rewitalizację niejednoznacznie rozumianej bułgarskiej „duchowości” (Anton Donczew). Pomimo formalnej izolacji tzw. Krajów Demokracji Ludowej od wpływów zachodnich, pewna zbieżność czasowa tego zjawiska z rodzącym się na Zachodzie Europy otwarciem niektórych kręgów prawicowych na neopogańską myśl faszystowską (Mikołejko, 1998a) wydaje się warta pogłębionego namysłu.

\section{Bestseller}

Wśród tekstów historiograficznych doby żiwkowowskiej, które podejmowały próby przewartościowania bułgarskiej tradycji, szczególne miejsce przypada książce Tonczo Żeczewa (1929-2000) pt. Български Великден или страстите български (1975), od chwili powstania należącej do kanonu lektur bułgarskiego humanisty. Ta eseistyczna, osobista w tonacji opowieść o historii dziewiętnastowiecznego ruchu na rzecz autonomii Cerkwi bułgarskiej pozostawała wielokrotnie wznawianym bestsellerem do końca epoki komunizmu i nadal, już wiele lat po śmierci autora, cieszy się zainteresowaniem. Po roku 1989, na fali wciąż niezakończonych rozliczeń z komunizmem zdarzały się próby deprecjacji Żeczewa jako politycznego konformisty (Н. Тодоров, 2000), a stawką mniej lub bardziej zniuansowanych dywagacji było wtedy coś więcej niż tylko dobre imię uczonego. Chodziło o wiarygodność książki, o to, czy należy na nią patrzeć jako na napisane na zamówienie władz politycznych narzędzie manipulacji świadomością zbiorową, czy też raczej jako na jeden 
ze znaczących aktów sprzeciwu wobec obowiązującej w okresie komunizmu polityki historycznej.

W obronie tej drugiej opcji wystąpiło wielu interpretatorów Żeczewa (Карев, 2014), jednak nawet oni nie mogli zaprzeczyć istnieniu pewnej kłopotliwej koincydencji zdarzeń. Otóż w połowie lat siedemdziesiątych XX wieku w sferze zarządzania kulturą w socjalistycznej Bułgarii zaszły kolejne zmiany, które wiązały się z wprowadzeniem w życie tzw. programu estetycznego wychowania narodu, któremu patronowała Ludmiła Żiwkowa (Еленков, 2008, s. 307-413). Wysoko umocowana w strukturach władzy państwowej córka Todora Żiwkowa szybko dała się poznać jako modernizatorka kultury, a zarazem zwolenniczka euroazjatyzmu, ze względów propagandowych dosyć zgrzebnie przykrojonego wówczas do reguł retoryki marksistowskiej. W obrębie tego projektu znalazło się również skromne miejsce dla rewitalizacji tradycji prawosławnej (Назърска, 2013, s. 240-251), która obok nurtów (neo)pogańskich współtworzyć miała synkretycznie rozumianą duchowość bułgarską (Szwat-Gyłybowa, 2006).

Tonczo Żeczew należał do kręgu Ludmiły Żiwkowej (Жечев, 1999). I to zapewne jej poparcie sprawiało, że służby bezpieczeństwa, jakoby odnoszące się z dezaprobatą do propagowanych przezeń idei (o czym donosiła plotka), nie posunęły się do drastycznych kroków (Жечев, 1995, s. 51). Jeden z badaczy dorobku Żeczewa, Jani Miłczakow, w artykule „Българският Великден“като консервативна утопия (2014) nie pominął milczeniem ani kłopotliwej kwestii niejednoznacznej sytuacji tego intelektualisty w państwie totalitarnym, ani też nie zanegował faktu późniejszej instrumentalizacji książki Żeczewa przez reżim, który: „в своя откровен «национално-патриотичен» и «консервативно-държавноохранителен» обрат от средата на 70-те охотно е разпознал като интелектуален инструмент «чорбаджийското», консервативното и еволюционното в Българския Великден“" (Милчаков, 2011).

Nawiązując do książki Karla Mannheima Ideologia i utopia (1929), Miłczakow nie bez racji umieścił Żeczewa w grupie „myślicieli pod presją” (skądinąd w towarzystwie znakomitych filozofów europejskich), ale jednocześnie stanął po stronie jego konserwatyzmu. Jako rozstrzygającą w tej materii uznał opinię świadka epoki - Borysa Dełczewa. Ten erudyta, frankofon, utalentowany krytyk literacki a zarazem odsunięty na bok apartczyk BRL-u, nieprzyjaznym okiem spoglądał na praktyki Ludmiły Żiwkowej i jej współpracowników (Делчев 1995). Jego osąd w sprawie Żeczewa jako konserwatysty uwikłanego w słowianofilstwo i filozofię Mikołaja Bierdiajewa, uznał więc Miłczakow za obiektywny: 
Б. Делчев определя дистанцирано Тончо Жечев като „даровит човек с консервативна мисловна нагласа“. Но по-нататък дневникът съдържа десетки иронични и хапливи подмятания именно за консерватизма на Т. Жечев. Неговата привързаност към руската славянофилска и историософска мисъл от XIX Делчев определя като „регресивна еволюция“, писането му - като „просмукано явно или скрито от консерватизбм, мистика, славянофилска идеализация на миналото в духа на бердяевщината“. Делчев ясно схваща „алтернативността“ на Тончожечевите идеи спрямо агонизиращата в две- три заклинателни формули, но все още непоклатимо официална догматика на „пролетарския интернационализъм, социалистическия реализъм и марксистко-ленинската естетика“. Критикът обаче съвсем не е убеден, че точно призивът на Т. Жечев „напред към миналото!“ може да освободи интелекта, културата и критичния анализ на социалните феномени (Милчаков, 2011).

W swoim studium Miłczakow podjął próbę rekonstrukcji stworzonej przez Żeczewa światopoglądowej korekty marksistowskiego materializmu historycznego. Zainteresowała go nie wartość naukowa książki Българскияm Великден, gdyż do jej warsztatu, umocowania metodologicznego czy pieczołowitości autora wobec źródeł odniósł się z dystansem; za cenną uznał raczej konfesyjno-historiozoficzną warstwę dzieła. Zdaniem Miłczakowa symbioza poetyki spowiedzi i traktatu, gdzie płaszczyzny temporalne mieszają się, a granica między językiem osobistego wyznania a językiem utopii ulega zatarciu, stała się w rękach Żeczewa elastycznym narzędziem ewokowania treści, dla których ostatecznie znalazł syntetyzującą metaforę w finalnym rozdziale „Българският Одисей“ и истината на неговото завръщане. Analizuја̨с tę koncepcyjnie najważniejszą, zdaniem badacza, partię tekstu przez pryzmat innych wypowiedzi Żeczewa (jego wywiadów czy esejów z czasem wydanych w zbiorze Mumъm за Oдисей z 1985 roku), Miłczakow dokonał jednak, jak się wydaje, pewnej symplifikacji przesłania autora, nie docierając do wszystkich odcieni semantycznych jego utopii konserwatywnej.

\section{Zamurowana niewiasta I}

Jeśli przyjmiemy za Miłczakowem, że Żeczew napisał pięćset trzydzieści dziewięć stron swego dzieła tylko po to, by stworzyć właściwy kontekst historyczny dla pięćdziesięciostronicowej interpretacji skromnego poematu Petko R. Sławejkowa Изворът на белоногата (Źródło Białonogiej, 1873), to temu epilogowi warto przyjrzeć się bliżej. 
$\mathrm{Na}$ gruncie historii literatury wspomniany poemat doczekał się wielu interpretacji, lecz Żeczew jako pierwszy przeprowadził próbę jego nobilitacji poprzez przypisanie mu cech mitu ${ }^{3}$ założycielskiego bułgarskiego liberalnego konserwatyzmu. Ta rewitalizacja skromnego dziełka Sławejkowa wynikała ze strategii Żeczewa, który sto lat od napisania poematu odniósł się do innego młodzieńczego gestu poety-publicysty, który w 1860 roku prowadził na łamach pisma „България“4 polemikę na temat przyszłości chrześcijaństwa u Bułgarów. Wrogo ustosunkowany do prób współpracy z Kościołem rzymskokatolickim, a zwłaszcza do prób utworzenia bułgarskiego Kościoła unickiego Sławejkow wielokrotnie powtarzał popularną później u potomnych myśl, iż Bułgarzy pozostaną prawosławni jedynie nominalnie, gdyż nie są oni ludźmi wiary (Славейков, 1860a). Za pozorną troską o duchowość rodaków kryła się, zdaniem historyka, przewrotna satysfakcja $\mathrm{z}$ ich indyferentyzmu religijnego $\mathrm{i}$ to w okolicznościach walki o niezależny Kościół (Жечев, 1980, s. 16). Być może to ta inspiracja sprawiła, że w działaniach dziewiętnastowiecznej aktywistów cerkiewnych sam Żeczew akcentował instrumentalizację Cerkwi i religii, ich podporządkowanie celom politycznym (Жечев, 1980, s. 17).

Тази свобода, с която българските дейци използуваха църковната организация, религията и нейните предания в национално-църковното движение, имаше за резултат укрепването ни в безверието, а победата да движението бележи началото на широкия размах на открито политическа революция за национално освобождение при явно спадане относителната тежест на църквата и религията в националния живот. С други думи, църковната борба направи така, че българите прегърнаха единствено религията на политиката (Жечев, 1980, s. 17).

Trudno jednak powiedzieć, czy w warunkach tego typu ograniczenia swobód twórczych (w istocie podważająca chrześcijańskość Bułgarów) zapośredniczona opinia Żeczewa stanowiła li tylko formę rytualnej daniny, składanej w tamtych latach (auto)cenzurze, która domagała się treści ateistycznych i antyzachodnich. Tak czy inaczej Żeczew wyostrzył obraz sytuacji w XIX wieku, ośmieszył unitów bułgarskich, przemilczał też wiele faktów z życia ludzi epoki,

${ }^{3}$ Na temat pojęcia „mit” oraz problemów z jego definiowaniem istnieje ogromna literatura przedmiotu, a zarazem obserwowane jest zjawisko trwałej infiltracji humanistycznego myślenia naukowego przez pojęcia wypracowane przez Mirceę Eliadego (Eliade, 1970, 1998). W artykule odwołuję się do jego rozumienia mitu archaicznego, ale też do kategorii interpretacyjnych zaproponowanych swego czasu przez Leszka Kołakowskiego (1982) oraz do pojęcia mitu politycznego w ujęciu Stanisława Filipowicza (1988) i Tadeusza Biernata (1989).

${ }_{4}^{4}$ Pismo wychodziło w Carogrodzie przy wsparciu francuskiej misji katolickiej. 
które mogły świadczyć o żywotności i sile formacyjnej ich światopoglądu religijnego. Historię walki o niezależność Cerkwi Żeczew przedstawił jako niejednoznaczną w sensie aksjologicznym historię zmagań, trudów, negocjacji politycznych, intryg, ludzkiego cierpienia, ofiarności, ale także jako historię dzieła porzuconego w chwili triumfu, dzieła, które nie mogło się ostać wobec braku fundamentu wiary i szacunku dla tradycji:

колкото по-изистанал, патриархален и социално-икономическо отношение народ се възражда сред народи [...] толкова е по-податлив в склонен към най-радикалните, най-дръзко разрушителните идеи и лозунги по отношение на стария строй на живота, толкова по-склонен е да прегърне знамето на най-бързия и ефектен прогрес (Жечев, 1980, s. 19).

Uczyniwszy Petka R. Sławejkowa głównym bohaterem omawianego tu epilogu książki pt. Българският Великден, Żeczew zinterpretował kryzys, jakiego poeta doświadczył po sukcesie w postaci ustanowienia autonomii Cerkwi narodowej, jako reakcję na doświadczenie rozpadu wartości, które nie są już w stanie jednoczyć wspólnoty.

Jeśli spojrzymy na całość książki Żeczewa, to niewiele ona mówi na temat czasu budowania ${ }^{5}$ państwa bułgarskiego po kongresie berlińskim 1878 roku. Narracja kończy się na roku 1873; a granicę tę wyznacza moment powstania wspomnianego tu poematu Sławejkowa pt. Изворьт на белоногата. Ze względu na interesujący nas temat nie można jednak pominąć milczeniem rozdziału poprzedzającego epilog a zatytułowanego Спомени, размисли и следосвобожденска съдба на един българин от Възраждането, który poświęcony został powyzwoleńczym losom Todora Ikonomowa (1838-1892). Ten wykształcony w Kijowie teolog, o niejednoznacznym stosunku do zachodniego chrześcijaństwa (Икономов, 1885), niewygodny dla każdego środowiska politycznego, przez reżim Stambołowa wykluczony w życia publicznego, zniszczony materialnie, utraciwszy po tym wszystkim władze umysłowe, zmarł w nędzy niedługo po nieudanej próbie samobójstwa. Przejmujący finał życia tej postaci Żeczew uczynił symbolem losu najbardziej ideowych i bezinteresownych przedstawicieli pierwszego pokolenia bułgarskich „konserwatystów”. Do tej grupy włączył też absolwenta Sorbony, wybitnego działacza cerkiewnego i wysokiego urzędnika Porty Gawriła Krystewicza (1817-1898). Po wyzwolenia spod panowania osmańskiego, już jako gubernator Rumelii Wschodniej (1884-1885), a co za tym

${ }^{5}$ Znamienne jednak, że jedna z najważniejszych książek mówiących o tym okresie nosi tytuł Budowniczowie współczesnej Bułgarii. Zob. Радев (1990, 2009). 
idzie - traktowany przez rodaków jak namiestnik sułtana, Krystewicz został w upokarzający sposób usunięty z miasta przez groteskową parę - Czardafona Wielkiego i jego przebraną w hajducki strój narzeczoną. Tenże człowiek w 1872 roku był jedynym bodaj człowiekiem, który publicznie złożył świadectwo konfliktu sumienia z powodu oskarżeń o etnofiletyzm. Konstantyn Leontiew, rosyjski filozof i dyplomata, przeciwnik autonomii Cerkwi bułgarskiej, w artykule Панславизмът на Атон (1873) z szacunkiem dostrzegł w postawie Krystewicza manifestację prawdziwie chrześcijańskich wartości:

В началото на разгара на гръцко-българските дела беше, естествено, на страната на своите сънародници. Но той е човек лично вярващ, а не политик на Православието, както мнозинството гръцки и български архонти в наше време [...]. Отхвърлен от Патриаршията заедно с другите, той нямал покой; може би и жена му го уговаряла, но се свърши с това, че около Рождество се явил при Патриарха, паднал в нозете му и молил за себе си лично опрошение и прочастие от Вселенския престол [...]. От българска страна, разбира се, се посипаха обвинения в измяна, в предателство... А на нас този човек, в когото се бореха две високи чувства, пламенен патриотизъм и религиозност, и у когото победи чувството несъвременно, немодно [...] - на нас този човек, непобоял се от клевети и насмешки, внушава уважение [...]. Ако между гърците и българите имаше повече такива люде, като Гавриил ефенди, закърмени в духа на личното Православие, и по-малко такива, като лошия поет Славейко [...] разделението щеше да стане постепенно, без разрив и ракол (Г. Тодоров, 1998).

Natomiast zwrot, który pod wpływem traumatycznych doświadczeń początku lat siedemdziesiątych XIX wieku dokonał się w światopoglądzie niezbyt przez Leontiewa szanowanego Sławejkowa, Żeczew, przyznając się do inspiracji ze strony Konstantina Jirečka, nazwał powrotem bułgarskiego Odyseusza do Itaki:

Константин Иречек пръв даде най-сполучливото образно име на Петко Славейков, като го нарече „български Одисей“; „Изворът на Белоногата“ в духовно завръшане на българския Одисей към родната Итака, идеализирана в спомена и носталгията, въжделена в безбройни проключения, в чъжди крайща, в мизерията на големия град, в подемите и наденията на обществените борби (Жечев, 1980, s. 573).

Cóż to za kraina, do której mentalnie powrócił Sławejkow? W poemacie jest nią wyidealizowana bułgarska wieś, którą reprezentuje piękna, pracowita, skromna i wierna sielskiej, rodowej tradycji - Gergana. Nakłaniana przez tureckiego wielmożę do wyjazdu z nim do wielkiego miasta, stawia opór, przedkładając moralną wyższość świata skromnych potrzeb i czystości serca (ogród, ikony, związki rodowe, 
obyczaj) nad ułudę zbytku, niosącego duchową śmierć i wiązanego z cywilizacją miejską. Symbolem tej ostatniej pozostawał, choć nie zostało to w poemacie dopowiedziane, Carogród/Stambuł - osmańska metropolia, modernizująca się na wzór zachodni, przestrzeń zwyrodniała i wroga wartościom preferowanym przez konserwatystów bez względu na ich afiliację narodową (Jedlicki, 2000, s. 111-112). Jak podkreśla Żeczew, wszystkie argumenty bohaterki mają charakter „przedkulturowy”, tj. opierają się na archaicznej mądrości kolektywu sprzed poznania cywilizacji okcydentalizującego się wielkiego miasta:

\begin{abstract}
Всички прелестни отговори на Гергана на съблазните на пашата са предкултурни и зотова силни и безприкословни, целият неин морал е отпреди познанието и затова е цялостен, всичките и аргументи срещу града са изконно селски и зотова убедителни. [...] Славейков [...] ни рисува някогашния български рай, където още не е било посадено дървото на познанието, рай, пълен с чистота, ред, вярност и обредност, дето всичко се ражда, расте, живее и умира под благодат (Жечев, 1980, s. 571-572).
\end{abstract}

I chociaż w poemacie turecki pasza okazuje szacunek dla decyzji Gergany i pozwala pozostać jej we wsi, przypadek (a właściwie intryga złych mocy) sprawia, że bohaterka traci życie. Dzieje się to za sprawą budowniczych ujęcia wody - czeszmy, którzy stają się nieświadomymi wykonawcami woli nienawidzącego dziewczyny demona (wity). Wierni starodawnym rytuałom magicznym zamurowują cień Gergany w fundamentach wznoszonej budowli; zgodnie z oczekiwaniami ofiara wkrótce umiera, by od tej pory żyć wiecznie jako dobry duch budowli.

\title{
Zamurowana niewiasta II
}

Wykorzystany przez Sławejkowa archaiczny motyw ofiary zakładzinowej popularny był w folklorze narodów bałkańskich oraz u Rumunów (Eliade, 2002, s. 155-179), a sam zwyczaj w XIX wieku w złagodzonej wersji wciąż praktykowany. Jak wiadomo, jako jeden z pierwszych upublicznił te informacje Vuk Karadżić, wydając drukiem balladę o budowaniu twierdzy w Skadarze (3идаюе Скадра, 1815). W roku 1846 Zachari Kniażeski w biuletynie rosyjskiego ministerstwa oświaty informował o macedońskim zwyczaju zamurowywania czyjegoś (uchwyconego przez pomiar nicią) cienia w fundamentach budowanego domu. Jak twierdził autor, wierzono, że człowiek, którego cień zamurowano, po czterdziestu dniach umrze i stanie się duchem nowej budowli (Арнаудов, 1972, s. 224). Na ofiary 
najczęściej wybierano kobiety; zwykle przypadkowe osoby, jednak pieśń ludowa dodawała narracji dramatyzmu, ofiarą czyniąc żonę/siostrę najstarszego rangą lub najmłodszego murarza (Арнаудов, 1972, s. 221-460). Wierzono, że zespolenie ofiary $\mathrm{z}$ obiektem odbywa się w momencie zgonu i ma wymiar etyczny, gdyż po śmierci człowiek ten (w jedności z najtrwalszym bytem, jakim jest kamień) zyskuje nieśmiertelność i po wsze czasy może służyć dobrostanowi wspólnoty. Na przestrzeni wieków ofiara ludzka zastępowana była zwierzęcą lub przez inny symboliczny artefakt. Materiał rzeczowy jest bogaty, jednak nigdzie w Europie poza obszarem bałkańskim (w tym wypadku granicą występowania są środkowe Węgry) nie zostało poświadczone istnienie tak wielu tekstów folkloru o zamurowanej kobiecie (Арнаудов, 1972). Przez reprezentantów narodowo afiliowanych badań stawało się to nierzadko okazją do polemik, których stawką było prawo starszeństwa, a więc de facto autorstwo ballady.

Alan Dundes - słusznie lub nie - powiązał to z „zaściankowym nacjonalizmem" autorów (Dundes, 1996, s. 194). Trudno jednak mówić o zaściankowości, gdy pada nazwisko Mircea Eliade, kłopotliwego autorytetu zachodniej humanistyki XX wieku, który rozsławił rumuńską wersję ballady ${ }^{6}$. Znał on, pisząc swój tekst, rozległą rozprawę Вградена невеста (1919) Michaiła Arnaudowa, który dał bogaty materiałowo, wieloaspektowy ogląd bałkańskich i sąsiadujących z Bałkanami źródeł folklorystycznych (albańskich, bułgarskich, greckich, serbskich, rumuńskich, węgierskich, wołoskich) oraz ich bułgarskich - głównie literackich - parafraz. Eliade w niewielkim eseju Mistrz Manole i klasztor $w$ Argesz (1955) w centrum swojej uwagi postawił wersję rumuńską. Jego interpretacja opierała się na określonych założeniach estetycznych i metafizycznych. W rezultacie zaprezentował wyestetyzowaną w wieku XVII rumuńską wersję ballady Mistrz Manole i klasztor w Argesz ${ }^{7}$ jako sublimację „rumuńskiego ducha”. Przedstawiona przez niego ludowa wizja ofiary z człowieka jako gwarancji ustanawianego przez ludzi porządku (architektonicznego, kosmicznego), której pochwałę w wymiarze ahistorycznym starannie ukrył w pozornie bezstronnym, scjentystycznym wywodzie, nabiera szczególnego znaczenia w konfrontacji z głoszonymi przez rumuńskiego filozofa religii aż do końca

${ }^{6}$ Proces ten miał wszelako starsze korzenie, np. w ostatnich dziesięcioleciach powstały dwa niemieckojęzyczne teksty artystyczne, wykorzystujące rumuński wariant motywu zamurowania, na co zwracał uwage jeszcze Michaił Arnaudow: A. Fortesheim Manoli, rumänische Volkssage (1884) oraz Carmen Sylva Meister Manole (1891).

7 Zob. tekst ballady w przekładzie Jerzego Ficowskiego w: Antologia poezji rumuńskiej (1989, s. 78-86). 
II wojny światowej poglądami filofaszystowskimi, których nigdy później nie odrzucił, długo unikając i demaskacji, i ekspiacji (Leignel-Lavastine, 2010). Stawszy się po wojnie autorytetem w badaniach nad religiami świata, Eliade poprzez swoje prace uzyskał właściwie nieograniczony wpływ na zachodnie elity intelektualne i artystyczne, i to niezależnie od wyborów światopoglądowych poszczególnych środowisk (Turcanu, 2008). Jak zauważył Zbigniew Mikołejko, zmowę milczenia w sprawie przeszłości Eliadego przerwali dopiero w latach siedemdziesiątych XX wieku autorzy włoscy (Mikołejko, 1998a), co stanowiło niejako efekt uboczny ich zainteresowania badawczego twórcą tzw. tradycjonalizmu integralnego - Juliusem Evolą, który odegrał w faszystowskiej Europie niebagatelną rolę, dostarczając ideologii nazistowskiej uwiarygodnienia w języku neopogańskiej mistyki (Mikołejko, 1998b), a dziś jego idee przeżywają swoisty renesans na gruncie rosyjskim w myśli m.in. Aleksandra Dugina. Eliade, w deklaracjach światopoglądowych ostrożniejszy od Evoli, posługiwał się chrześcijańską siatką pojęć, gloryfikował męczeństwo, ofiarę z własnego i cudzego życia jako rodzaj mistycznej drogi do nowego, lepszego świata. Narracja ta narzucała skojarzenia z quasi-chrystologicznym paradygmatem „spokojnie przyjętej «nagłej śmierci»" (Eliade, 2002, s. 179) - ofiary z życia, złożonej w imię trwałości dzieła (materialnego i duchowego) służącego kolektywowi.

\section{Zamurowana niewiasta III}

Typologiczna zbieżność konceptu Toncza Żeczewa z przesłaniem Eliadego budzi wiele pytań, tym bardziej że nie powołał się na tekst Rumuna ${ }^{8}$. Pobieżnie tylko wspomniał nazwisko Michaiła Arnaudowa, badacza po przejęciu władzy przez komunistów skazanego wyrokiem sądu ludowego na dożywotnie więzienie za współpracę $\mathrm{z}$ „faszyzmem”, na wiele lat wykluczanego z życia naukowego (Димитров, 2014). Jako uczony autor ten szukał zobiektywizowanej wiedzy i unikał podszytego nacjonalistyczną emfazą mitologizowania (Кунчева, 2006, s. 397-415). Jego rozprawa Вградена невеста w 1972 roku doczekała się pierwszego po wojnie wznowienia. Z pozytywistycznym deskryptywizmem i szacunkiem dla szczegółu omawiając

${ }^{8}$ Przekłady dzieł Eliadego pojawiły się w Bułgarii dopiero w latach dziewięćdziesiątych XX wieku, już po upadku systemu komunistycznego, w okresie, kiedy krytyka Eliadego w Stanach Zjednoczonych osiągnęła swój zenit. 
motyw zamurowanej niewiasty w folklorze południowo-wschodniej Europy oraz jego bułgarskie literackie parafrazy, nie wyolbrzymiał rangi materiału bułgarskiego, lecz go porządkował według kryteriów chronologicznych, geograficznych i artystycznych. Chociaż Żeczewa mogły zainspirować badania Arnaudowa, w swojej interpretacji poematu Sławejkowa poszedł jednak $\mathrm{w}$ innym kierunku, zespalając metodę biograficzną z alegorezą. W efekcie zinterpretował dziewietnastowieczny utwór jako ewokację światopoglądu samego poety, który po kryzysie, wywołanym rozczarowaniem do środowiska działaczy narodowych, odnaleźć miał według Żeczewa sens życia i spokój ducha w powrocie do rodzimych wartości rdzennych. Aby wydobyć pulsującą u źródeł mądrość kultury ludowej, badacz posłużył się nieco sztuczną opozycją Sławejkow - Dostojewski, skonstruowaną wokół pytań o ontologię zła. Żeczew podkreślił, że bułgarski poeta w odróżnieniu od Dostojewskiego, któremu nie udało się pokonać aporii, zawartej w pytaniu o odpowiedzialność Boga za cierpienie niewinnych (Жечев, 1980, s. 587), odrzucił teologiczny przymus szukania odpowiedzi na to pytanie. W rezultacie Żeczew, idąc śladami Sławejkowa, wydobył wyższość mądrości płynącej z pierwotnego bułgarskiego synkretyzmu nad chrześcijaństwem i jego nieporadną teodyceą Wykonał znamienny gest, eksponując terapeutyczną moc archaicznego mitu, który oferuje człowiekowi pogodzenie się ze światem „konieczności”:

\begin{abstract}
Той ни казва - така става винаги, всяка промяна е върху кости, такъв е животът, ние сме не ответници на това питане, всъщност никой не ни пита, но ако искате да правите чешма от стария бистър извор, ще жертвувате Гергана [...] Той е по-близо до първообраза на легендата, до онези, които са чували непознатия тайнствен глас, вопиющ за кръв и жертва, за да закрепи колебливите им усилия в новите градежи, отколкото до съдбоносното условие на възрожденското съзнание изобщо само да бъде разпоредител на света, да взема на плещите си, на свой риск отговорността, освободено от бог и вяра, освен вярата в себе си. Всичко това е рядък, неповторим епизод в живота на идеите, където органично се сливат българското възрожденско съзнание с народния дух и мъдрост. Нашето възрожденско съзнание се връща в потъва в лоното на народния дух и мъдрост, там намира помощ и опора пред напиращите морални въпроси на българското развитие (Жечев, 1980, s. 588-589).
\end{abstract}

Motyw spokojnej akceptacji ofiary z życia jako zrządzenia Losu u Żeczewa został więc zaprezentowany trójstopniowo: na poziomie folkloru jako wyraz archaicznej mądrości ludu, na poziomie tekstu literackiego jako efekt owocnego spotkania różnych idei, których splot sprzyjał integracji psychicznej podmiotu bezradnego wobec etycznych problemów „bułgarskiego rozwoju”, 
i wreszcie - na poziomie metatekstu jako punkt odniesienia dla rzeczywistości lat siedemdziesiątych XX wieku, naznaczonej marksistowskim piętnem historycznej konieczności. Bułgarski czytelnik, znękany szarzyzną i jałowością socrealistycznej monokultury, dzięki tym częściowo wyrażonym w języku ezopowym wskazówkom mógł się rozpoznać jako „bułgarski Odyseusz”, wolny od przymusu rozpamiętywania doświadczonych nieszczęść, wolny od opresji wstydu z powodu własnego konformizmu wobec politycznej przemocy i odnajdujący powrotną drogę do samego siebie, tj. do archaicznego jądra tożsamości sprzed „fałszywej” kultury nowoczesnej.

\section{Bułgarski Odyseusz}

Czy w tym kontekście intelektualny gest Żeczewa może być uznany za wyraz całkowitego braku synchronii z polityką symboliczną reżimu komunistycznego? Czy było to świadectwo nonkonformizmu proroka, w obliczu zbliżającej się hekatomby głoszącego konieczność powrotu do wartości pierwotnych? Czy też przeciwnie, stanowi on formę podszytej hipokryzją „zdrady klerka” (Benda, 2014)? A może mamy prawo mówić o swoistej (zainspirowanej przez polityków lub nie) harmonii między potrzebami specjalistów od socjotechniki, sięgających po nowe formy ideologicznej perswazji, a utopią konserwatywną Żeczewa (jak by chciał Miłczakow), jego progresywno-regresywnym projektem, wyrażanym przez eseistę w haśle „naprzód ku przeszłości”, a rozumianym jako narzędzie rewitalizacji twórczego potencjału Bułgarów w warunkach wygasania i wyjałowienia systemu motywacyjnego, jaki w sferze intelektu był w stanie wygenerować $\mathrm{w}$ tamtej dobie upartyjniony marksistowski materializm?

Eseistyka Żeczewa dostarcza podstaw dla wielu sprzecznych interpretacji, choć on sam post factum usiłował dać jednoznaczną wykładnię swoich intencji w tekstach napisanych już w warunkach demokracji, np. w szeroko komentowanym eseju Болки от текущото (1995). I niejako wbrew tej próbie stworzenia przezeń autoportretu postępowego konserwatysty (1995), filozof Bojan Manczew odczytał teksty Żeczewa z okresu żiwkowskiego w duchu hermeneutyki podejrzeń. W artykule pt. Модерност и антимодерност. Българският наиионалекзотизъм uznał on omawiany tu projekt powrotu do kojącego porządku pierwotnych wartości (Жечев, 1994) za jedną z form realizacji założeń nowej nacjonalistycznej estetyki (egzotyki), której w latach 
siedemdziesiątych patronowała Ludmiła Żiwkowa (Манчев, 2003). Ów mit retro-utopii Żeczew w pełni rozwinął jednak dopiero po śmierci Żiwkowej, w swoich esejach z lat osiemdziesiątych, a zwłaszcza w Mumøm за Одисец̆ (1989). Zdystansowany wobec dionizyjsko-ekstatycznego nurtu tej estetyki Żeczew pragnął mu przeciwstawić taki system wartości, który byłby syntezą doświadczenia nowoczesności, bułgarskiego ludowego pragmatyzmu i dość niedogmatycznie rozumianego prawosławia. Trajektoria po Eliadowsku rozumianego „wiecznego powrotu” (Eliade, 1998) tego bułgarskiego Odyseusza prowadzić miała od aksjologicznego chaosu ku ładowi przestrzeni oswojonej. Umityczniony rozum praktyczny, widziany poprzez pryzmat ballady „bułgarskiego Odyseusza“ - Sławejkowa i motywu „zamurowanej niewiasty”, stawał się u Żeczewa jednym z gwarantów ocalenia przed żywiołem zbiorowych emocji, zorientowanych na destrukcję, a znajdujących pożywkę w bułgarskim nihilizmie, z którym walkę Żeczew uczynił lejtmotywem swojej eseistyki po przełomie demokratycznym 1989 roku, kiedy to już jawnie deklarował zwrot ku tradycji chrześcijańskiej i nawoływał inteligencję bułgarską do metanoi:

Българската интелигенция се нуждае от ново кръщение, от покръстване в елемнтарните християнски истини. Ние ставаме полодородна почва за най-разрушителните идеи, за празни блянове, за красиви илюзии предимно от липса на християнско възпитание, от вкоренено езичество. [...] Лечението и спасението може да стане само на основата на християнската традиция и култура, а те ни говорят - спасяващият а не разрушаващият ще се спаси! (Жечев, 1995, s. 125-126).

Widać tu zatem pewną ewolucję. O ile w Български Великден или страстите български Żeczew wydobył różnicę między bolesnymi aporiami chrześcijaństwa a niosącym ukojenie mitem i postawił nacisk na archaiczny mit, o tyle w późniejszych tekstach akcenty rozłożył w inny sposób. Mit „zamurowanej niewiasty" zredukował do podszytej moralizatorstwem pochwały ofiarnego tworzenia-budowania, zaś mit „wiecznego powrotu” podporządkował idei rewitalizacji tradycji patriarchalnej i prawosławia. Znamiennym faktem jest, iż punktem odniesienia dla swych rozważań uczynił mistyczne prawosławie rosyjskie i jego filozoficzne interpretacje:

за да разберете ставащото в съвременния свят, трябва да почнете не с модерните, новите и най-новите философи, социолози, политолози, историци, литературоведи, а с пророческа руска мисъл от края на миналия и началото на нашия век, чиято верига започва с Фьодор Михайлович. [...] Завиждам на тия, които сега ще четат Достоевски. [...] Завиждам на тези, които сега ще се 
сродят със серафичния свят, изтънчената духовност на Власимир Соловьов, с могъщата творческа консервативна мисъл на К. Леонтиев и В. В. Розанов, с космизма на Фьодоров и Вернадски. [...] Завиждам на всички, които за пръв път ще се докоснат до напрегната и трагична мисъл на Беряев, Д. Мережковски, С. Булгаков, И. Илин, П. Вишеславец, С. Трубеской, П. Флоренски, Г. Шпет, Е. Трубецкой, А. Лосев, В. Зенковски. Това е философия на любовта, любовта като творческа сила, за Бога като Любов, способен да преобрази човека и вселената, философия на съборността като хармония на единичното с общото, философия на космическото предназначение на човека (Жечев, 1995, s. 53-54).

Odpowiedź tych członków młodszego pokolenia pisarzy bułgarskich, którzy po 1989 roku ustosunkowali się do mitu bułgarskiego Odyseusza brzmi: „nie”. Twórcy tego kręgu (Мерджански, 1997; Златанов, 1997; Тенев, 1997-1998) odrzucili zarówno wiarę w możliwość rewitalizacji utopii przeszłości, jak i wiarę $\mathrm{w}$ istnienie nadrzędnej prawdy transcendentnej. Odmówili też udziału w rytuale wiecznego powrotu, czyniąc Odyseusza, jak pisze Manczew, jedynie przewrotną poetycką figurą negatywnej epifanii'. Jednak nie jest to jedyny wariant reakcji na mitotwórstwo Żeczewa. Wśród badaczy folkloru i tradycji trackiej znajdują się bowiem uczeni, którzy kontynuują jego sposób rozumowania i dla podniesienia uniwersalnej rangi kultury bułgarskiej mit „zamurowanej niewiasty” uznają za archaiczną antycypację ofiary Chrystusa oraz lokalny (a zarazem pierwotny) wariant prechrześcijańskiej etyki (Георгиева, 2012; Николова, 2008, s. 44-45). Ze względu na brak umocowania tego typu interpretacji w teologii prawosławnej, uczeni ci w świadomy lub nieświadomy sposób przyczyniają się do dalszego rozmywania się semantyki pojęć chrześcijańskich. Powstały w wyniku stosowania logiki asocjacyjnej amalgamat kategorii przedchrześcijańskich, chrześcijańskich i postchrześcijańskich, nie sprzyja rozróżnianiu paradygmatów. Sprzyja natomiast szerzeniu się praktyk tej frakcji dawnej lewicy komunistycznej, która na długo przed przewrotem demokratycznym wykonała zwrot ku nowej, tym razem „lewicowej” wersji przedwojennego (w nomenklaturze reżimu komunistycznego zwanego "faszystowskim”) tradycjonalizmu integralnego. Po 1989 roku ta sama grupa aktywistów dokonała kolejnej wolty światopoglądowej, tym razem obierając prawosławie lokowane w orbicie „Русский мир“. Jednak to już inny, domagający się uwagi badaczy temat.

9 „Така Одисей, от фигура на национално-политическото, се превръща във фигура на преобърнатото, негативно поетическо сакрално, което не предполага предшестваща трансцендентална истина (идея, Бог, Родина), а явява истината, извайва я - в смисъла на plattein - ex nihilo, в екстаза на негативната епифания" (Манчев, 2003). 


\section{BIBLIOGRAFIA}

Antologia poezji rumuńskiej. (1989). (J. Rogoziński, Red.) (T. 1). Warszawa: PIW.

Benda, J. (2014). Zdrada klerków. Warszawa: Wydawnictwo Krytyki Politycznej.

Biernat, T. (1989). Mit polityczny. Warszawa: PWN.

Dundes, A. (1996). The ballad of “walled-up wife”. W: A. Dundes (Red.), The walled-up wife: A casebook (ss. 185-207). Wisconsin: The Univesity of Wisconsin Press.

Eliade, M. (1970). Sacrum, mit, historia. (A. Tatarkiewicz, Tłum.). Warszawa: PIW.

Eliade, M. (1998). Mit wiecznego powrotu. (K. Kocjan, Tłum.). Warszawa: Wydawnictwo KR.

Eliade, M. (2002). Mistrz Manole i klasztor w Argesz. W: M. Eliade, K. Kocjan (Tłum.), Od Zalmoksisa do Czyngis-chana (ss. 155-179). Warszawa: PWN.

Filipowicz, S. (1988). Mit i spektakl władzy. Warszawa: PWN.

Jedlicki, J. (2000). Świat zwyrodniały: Lęki i wyroki krytyków nowoczesności. Warszawa: Wydawnictwo Sic!

Kołakowski, L. (1982). Obecność mitu. Paryż: Instytut Literacki.

Leignel-Lavastine, A. (2010). Cioran. Eliade. Ionesco: O zapominaniu faszyzmu: Trzech intelektualistów rumuńskich $w$ dziejowej zawierusze. (I. Kania, Tłum.). Kraków: Universitas.

Mannheim, K. (1986). Myśl konserwatywna. (S. Magala, Tłum.). Warszawa: Kolegium Otryckie

Mikołejko, Z. (1998a, sierpień 14). Niewidomy w Jassach. Gazeta Wyborcza, s. 22.

Mikołejko, Z. (1998b). Mity tradycjonalizmu integralnego: Julius Evola i kultura religijno-filozoficzna prawicy. Warszawa: IFiS PAN.

Szwat-Gyłybowa, G. (Red.). (2011). Leksykon tradycji bułgarskiej. Warszawa: SOW

Szwat-Gyłybowa. G. (2006). Projekt desekularyzacji kultury bułgarskiej w czasach Żiwkowowskich? W: J. Królak \& J. Molas (Red.), Slavica leguntur: Aktualne problemy badawcze slawistyki (ss. 333-341). Warszawa: Wydawnictwo UW.

Turcanu. F. (2008). Mircea Eliade: Więzień historii. (R. Reszke, Tłum.). Warszawa: Wydawnictwo KR.

Арнаудов, М. (1972). Вградена невеста. W: М. Арнаудов, Студии върху българските обреди и легенди (ss. 221-460). София: БАН.

Везенков, А. (2013). Османизмът като политика на идентичността през епохата на Танзимата. Pobrano 10 października 2015, z http://www.librev.com/index.php/prospects -bulgaria-publisher/2048-osmanizam-tanzimat

Георгиева, И. (2012). Вградена невеста: Пример за битово християнство. Българска наука, (75). Pobrano 11 marca 2015, z http://nauka.bg/a/вградена-невеста-пример-за -битово-християнство

Даскалов, Р. (2002). Как се мисли българското Възраждане: Историограбско проучване. София: ЛИК.

Делчев, Б. (1995). Дневник. София: ИК „Народна култура”. 
Димитров, Е. ( 2014). Публицистиката на Михаил Арнаудов. София: Изток - Запад.

Добрев, Д. (2011). Кой е Тончо Жечев? W: А. Горчев et al. (Red.), 80 години от рождението на Тончо Жечев (ss. 3-13). Велико Търново: Faber.

Еленков, И. (1998). Родно и дясно: Принос към историята на несбъднатия „десен проект“ в България от времето между двете световни войни. София: Лик.

Еленков, И. (2008). Културният фронт: Българската култура през епохата на комунизма - политическо управление, идеологически основания, институционални режими. София: ИИБМ.

Енчев, М. (2011). Телемах се учи да се връща. W: А. Горчев et al. (Red.), 80 години от рождението на Тончо Жечев (ss. 59-65). Велико Търново: Faber.

Жечев, Т. (1980). Български Великден или страстите български. София: Народна младеж.

Жечев, Т. (1989). Митът за Одисей. София: Български писател.

Жечев, Т. (1994). Лебеда и смғртта. София: Христо Ботев.

Жечев, Т. (1995). Болки от текущзото. София: Летописи.

Жечев, Т. (1999). Като свидетелство пред съд. W: Ж. Костадинова, Пророчествата на Ванга за човешките съдби: Книга втора (ss. 190-197). София: Труд.

Живков, Ц. (2001). Един от милиона: За Тончо Жечев и „Българският Великден“. Литературен форум, (13). Pobrano 3 sierpnia 2016, z http://www.slovo.bg/old/litforum/113/czhivkov.htm

Златанов, 3. (1997). На острова на копрофилите. София: Свободно поетическо общество.

Икономов, Т. (1885). Протестанската пропаганда у насъ и нейнить ползи за България. Руссе: Скоропечатница на в. Славянинъ.

Карев, Г. (2014). Тончо Жечев и неговото завръщане към Итака - част 1. Култура, (11). Pobrano 30 lipca 2016, z http://www.librev.com/index.php/discussion-culture -publisher/2308-toncho-zhechev

Китромилидис, П. (1999). От кръста към флага: Аспекти на християнството и национализма на Балканите. (В. Тодоров, Тłum.). София: Издателство Парадигма.

Кунчева, Р. (2006). Методологическата позиция на Михаил Арнаудов: Наблюдения върху „Основи на литературната наука”. W: А. Георгиева (Red.), Академик Михаил Арнаудов - ученият и творецьт (ss. 397-415). София: АИ „Проф. Марин Дринов”.

Манчев, Б. (2002). Вечното завръщане на Одисей. Култура, (23). Pobrano 12 czerwca 2016, $\mathrm{z}$ http://www.kultura.bg/bg/article/view/6957

Манчев, Б. (2003). Модерност и антимодерност: Българският националекзотизбм. Електронно издателство LiterNet. Pobrano 12 czerwca 2016, z http://liternet.bg/publish2/ bmanchev/modernost1.htm

Мерджански, К. (1997). Митът за Одисей в новата буколическа поезия. София: Агенция Има.

Милчаков, Я. (2011). „Българският Великден” като консервативна утопия. Pobrano 5 sierpnia 2016, z http://www.librev.com/index.php/arts-theory-publisher/2325-2014-03-04-12-23-34

Мишкова, Д. (2005). Балкански визии за Европа през деветнайсети век: Канали на културен пренос и интелектуален контекст. Pobrano 10 lipca 2016, z http://www.bulgc18. com/occidentalism/Mishkova2.htm\#_ednref11 
Назърска, Ж. (2013). Религия и комунизъм в България: Устни свидетелства за религията, православната църква и личната религиозност през втората половина на XX век. W: A. Лулева (Red.), Българският ХХ век: Колективна памет и национална идентичност (ss. 240-251). София: ИК „Гутенберг“.

Николова, В. (2008). Богомилството: Предобрази и идеи: В пбтя от Първи до Трети завет. София: М-8-М.

Николов-Зиков, П. (2011). Раждането на българския консерватизбм. София: Парадигма.

Радев, С. (1990). Строителите на съвременна България (Т. 1-2). София: Български писател.

Радев, С. (2009). Строителите на съвременна България (Т. 3). София: УИ „Св. Климент Охридски".

Речник на чуждите думи в българския език. (1976). (В. Георгиев et al., Red.). София: Наука и Изкуство.

Славейков, П. Р. (1860а). Глас от пусто горе Телелейско. България, (59), 92.

Славейков, П. Р. (1860b). Глас от пусто горе Телелейско. България, (68), 241.

Тенев, Г. (1997-1998). Одисей Периагон. Демократически преглед, (34), 123-144.

Тодоров, Г. (1998). Забравената почтеност: Защо забравихме Гаврил Кръстевич. Култура. Pobrano 3 sierpnia 2016, z http://www.kultura.bg/bg/article/view/1830

Тодоров, Н. (2000). Оставете на мира праха на Тончо Жечев! Литературен форум, 429, (9). Pobrano 3 sierpnia 2016, z http://www.slovo.bg/old/litforum/006/ntodorov.htm

Якимов, Г. (2003). Панталей Кисимов: Живот и дейност: Принос към изследването на идеята на турско-българския дуализъм през Възраждането. София: АИ „Проф. Марин Дринов".

\section{BIBLIOGRAPHY}

\section{(TRANSLITERATION)}

Antologia poezji rumuńskiej. (1989). (J. Rogoziński, Ed.) (Vol. 1). Warszawa: PIW.

Arnaudov, M. (1972). Vgradena nevesta. In M. Arnaudov, Studii vŭrkhu bŭlgarskite obredi i legendi (pp. 221-460). Sofiia: BAN.

Benda, J. (2014). Zdrada klerków. Warszawa: Wydawnictwo Krytyki Politycznej.

Biernat, T. (1989). Mit polityczny. Warszawa: PWN.

Daskalov, R. (2002). Kak se misli bŭlgarskoto Vŭzrazhdane: Istoriografsko prouchvane. Sofiia: LIK.

Delchev, B. (1995). Dnevnik. Sofiia: IK „Narodna kultura”.

Dimitrov, E. ( 2014). Publitsistikata na Mikhail Arnaudov. Sofiia: Iztok - Zapad.

Dobrev, D. (2011). Koĭ e Toncho Zhechev? In A. Gorchev et al. (Eds.), 80 godini ot rozhdenieto na Toncho Zhechev (pp. 3-13). Veliko Tŭrnovo: Faber. 
Dundes, A. (1996). The ballad of “walled-up wife". In A. Dundes (Ed.), The walled-up wife: A casebook (pp. 185-207). Wisconsin: The Univesity of Wisconsin Press.

Elenkov, I. (1998). Rodno i diasno: Prinos kŭm istoriiata na nesbŭdnatiia „desen proekt“ $v$ Bŭlgariia ot vremeto mezhdu dvete svetovni voini. Sofiia: Lik.

Elenkov, I. (2008). Kulturniiat front: Bŭlgarskata kultura prez epokhata na komunizma - politichesko upravlenie, ideologicheski osnovaniia, institutsionalni rezhimi. Sofiia: IIBM.

Eliade, M. (1970). Sacrum, mit, historia. (A. Tatarkiewicz, Trans.). Warszawa: PIW.

Eliade, M. (1998). Mit wiecznego powrotu. (K. Kocjan, Trans.). Warszawa: Wydawnictwo KR.

Eliade, M. (2002). Mistrz Manole i klasztor w Argesz. In M. Eliade, K. Kocjan (Trans.), Od Zalmoksisa do Czyngis-chana (pp. 155-179). Warszawa: PWN.

Enchev, M. (2011). Telemakh se uchi da se vrŭshta. In A. Gorchev et al. (Eds.), 80 godini ot rozhdenieto na Toncho Zhechev (pp. 59-65). Veliko Tŭrnovo: Faber.

Filipowicz, S. (1988). Mit i spektakl władzy. Warszawa: PWN.

Georgieva, I. (2012). Vgradena nevesta: Primer za bitovo khristiianstvo. Bŭlgarska nauka, (75). Retrieved 11 March 2015, from http://nauka.bg/a/вградена-невеста-пример-за-битово-християнство

Ikonomov, T. (1885). Protestanskata propaganda u nas i neiniitie polzi za Bŭlgariia. Russe: Skoropechatnica na v. Slavianin.

IAkimov, G. (2003). Pantalĕ Kisimov: Zhivot i deı̆nost: Prinos kŭm izsledvaneto na ideiata na tursko-bŭlgarskiia dualizŭm prez Vŭzrazhdaneto. Sofiia: AI „Prof. Marin Drinov”.

Jedlicki, J. (2000). Świat zwyrodniały: Lęki i wyroki krytyków nowoczesności. Warszawa: Wydawnictwo Sic!

Karev, G. (2014). Toncho Zhechev i negovoto zavrŭshtane kŭm Itaka - chast 1. Kultura, (11). Retrieved 30 July 2016, from http://www.librev.com/index.php/discussion-culturepublisher/2308-toncho-zhechev

Kitromilidis, P. (1999). Ot krŭsta kŭm flaga: Aspekti na khristiianstvoto i natsionalizma na Balkanite. (V. Todorov, Trans.). Sofiia: Izdatelstvo Paradigma.

Kołakowski, L. (1982). Obecność mitu. Paryż: Instytut Literacki.

Kuncheva, R. (2006). Metodologicheskata pozitsiia na Mikhail Arnaudov: Nabliudeniia vŭrkhu „Osnovi na literaturnata nauka”. In A. Georgieva (Ed.), Akademik Mikhail Arnaudov - ucheniiat i tvoretsŭt (pp. 397-415). Sofiia: AI „Prof. Marin Drinov”.

Leignel-Lavastine, A. (2010). Cioran. Eliade. Ionesco: O zapominaniu faszyzmu: Trzech intelektualistów rumuńskich $w$ dziejowej zawierusze. (I. Kania, Trans.). Kraków: Universitas.

Manchev, B. (2002). Vechnoto zavrŭshtane na Odiseř. Kultura, (23). Retrieved 12 June 2016, from http://www.kultura.bg/bg/article/view/6957

Manchev, B. (2003). Modernost i antimodernost: Bŭlgarskiiat natsionalekzotizŭm. Elektronno izdatelstvo LiterNet. Retrieved 12 June 2016, from http://liternet.bg/publish2/bmanchev/ modernost1.htm

Mannheim, K. (1986). Myśl konserwatywna. (S. Magala, Trans.). Warszawa: Kolegium Otryckie Merdzhanski, K. (1997). Mitŭt za Odiseı̆ v novata bukolicheska poeziia. Sofiia: Agentsiia Ima. 
Mikołejko, Z. (1998a, August 14). Niewidomy w Jassach. Gazeta Wyborcza, s. 22.

Mikołejko, Z. (1998b). Mity tradycjonalizmu integralnego: Julius Evola i kultura religijno-filozoficzna prawicy. Warszawa: IFiS PAN.

Milchakov, I. (2011). „Bŭlgarskiiat Velikden” kato konservativna utopiia. Retrieved 5 August 2016, from http://www.librev.com/index.php/arts-theory-publisher/2325-2014-03-04-12-23-34

Mishkova, D. (2005). Balkanski vizii za Evropa prez devetnaǐseti vek: Kanali na kulturen prenos i intelektualen kontekst. Retrieved 10 July 2016, from http://www.bulgc18.com/ occidentalism/Mishkova2.htm\#_ednref11

Nazŭrska, Z. (2013). Religiia i komunizŭm v Bŭlgariia: Ustni svidetelstva za religiiata, pravoslavnata tsŭrkva i lichnata religioznost prez vtorata polovina na XX vek. In A. Luleva (Ed.), Bŭlgarskiiat XX vek: Kolektivna pamet i natsionalna identichnost (pp. 240-251). Sofiia: IK „Gutenberg“.

Nikolova, V. (2008). Bogomilstvoto: Predobrazi i idei: V pŭtia ot Pŭrvi do Treti zavet. Sofiia: M-8-M.

Nikolov-Zikov, P. (2011). Razhdaneto na bŭlgarskiia konservatizŭm. Sofiia: Paradigma.

Radev, S. (1990). Stroitelite na sŭvremenna Bŭlgariia (Vols. 1-2). Sofiia: Bŭlgarski pisatel.

Radev, S. (2009). Stroitelite na sŭvremenna Bŭlgariia (Vol. 3). Sofiia: UI „Sv. Kliment Okhridski”.

Rechnik na chuzhdite dumi v bŭlgarskiia ezik. (1976). (V. Georgiev et al., Eds.). Sofiia: Nauka i Izkustvo.

Slaveĭkov, P. R. (1860a). Glas ot pusto gore Teleleĭsko. Bŭlgariia, (59), 92.

Slaveĭkov, P. R. (1860b). Glas ot pusto gore Teleleĭsko. Bŭlgariia, (68), 241.

Szwat-Gyłybowa, G. (Ed.). (2011). Leksykon tradycji bułgarskiej. Warszawa: SOW.

Szwat-Gyłybowa. G. (2006). Projekt desekularyzacji kultury bułgarskiej w czasach Żiwkowowskich? In J. Królak \& J. Molas (Eds.), Slavica leguntur: Aktualne problemy badawcze slawistyki (pp. 333-341). Warszawa: Wydawnictwo UW.

Tenev, G. (1997-1998). Odiseй Periagon. Demokraticheski pregled, (34), 123-144.

Todorov, G. (1998). Zabravenata pochtenost: Zashto zabravikhme Gavril Krŭstevich. Kultura. Retrieved 3 August 2016, from http://www.kultura.bg/bg/article/view/1830

Todorov, N. (2000). Ostavete na mira prakha na Toncho Zhechev! Literaturen forum, 429, (9). Retrieved 3 August 2016, from http://www.slovo.bg/old/litforum/006/ntodorov.htm

Turcanu. F. (2008). Mircea Eliade: Więzień historii. (R. Reszke, Trans.). Warszawa: Wydawnictwo KR.

Vezenkov, A. (2013). Osmanizmŭt kato politika na identichnostta prez epokhata na Tanzimata. Retrieved 10 October 2015, from http://www.librev.com/index.php/prospects-bulgariapublisher/2048-osmanizam-tanzimat

Zhechev, T. (1980). Bŭlgarski Velikden ili strastite bŭlgarski. Sofiia: Narodna mladezh.

Zhechev, T. (1989). Mitŭt za Odiseŭ. Sofiia: Bŭlgarski pisatel.

Zhechev, T. (1994). Lebeda i smŭrtta. Sofiia: Khristo Botev.

Zhechev, T. (1995). Bolki ot tekushtoto. Sofiia: Letopisi. 
Zhechev, T. (1999). Kato svidetelstvo pred sŭd. In Z. Kostadinova, Prorochestvata na Vanga za choveshkite sŭdbi: Kniga vtora (pp. 190-197). Sofiia: Trud.

Zhivkov, T. (2001). Edin ot miliona: Za Toncho Zhechev i „Bŭlgarskiiat Velikden“. Literaturen forum, (13). Retrieved 3 August 2016, from http://www.slovo.bg/old/litforum/113/czhivkov.htm

Zlatanov, Z. (1997). Na ostrova na koprofilite. Sofiia: Svobodno poetichesko obshtestvo.

\section{Zamurowana niewiasta, Odyseusz i Butgarska Wielkanoc. Tonczo Żeczew w poszukiwaniu mitu konserwatywnego}

W artykule podejmuję refleksję nad książką bułgarskiego humanisty Tonczo Żeczewa Bułgarska Wielkanoc albo namiętności bułgarskie (1975), która w komunistycznej Bułgarii zdobyła status dzieła głoszącego ideę powrotu do wartości tradycyjnych. Dokonany przez niego (formalnie rzecz biorąc - wbrew ideologii marksistowskiej) quasi-konserwatywny zwrot światopoglądowy oparty został m.in. na dosyć złożonej, wielowarstwowej reinterpretacji poematu Petka R. Sławejkowa Źródło Białonogiej (1873) oraz na rewitalizacji mitów zamurowanej niewiasty oraz Odyseusza. Dowartościowanie przez Żeczewa wynalezionej tradycji archaicznej jako ostoi pierwotnej mądrości i mistyki stanowi interesujące świadectwo poszukiwań takiej idei „tradycjonalizmu integralnego”, która byłaby do pogodzenia z progresizmem epoki żiwkowskiej.

Słowa kluczowe: konserwatyzm, Źródło białonogiej, zamurowana niewiasta, tradycjonalizm, komunizm

\section{The Immured Woman, Odysseus and Bulgarian Easter: Toncho Zhechev and the Quest for a Conservative Myth}

This article reflects on Bulgarian Easter, or Bulgarian Passions, a 1975 book by the Bulgarian humanist Toncho Zhechev, once regarded in Communist Bulgaria as a call for a return to traditional values. Zhechev's quasi-conservative ideological turn (which in formal terms ran counter to the precepts of Marxist ideology) was based, among other things, on a complex and richly layered reinterpretation of Izvorat na belonogata, a poem by Petko R. Slaveykov (The Spring of the White-Legged Girl, 1873), and on its revitalisation of the myths of the immured woman and of Odysseus. The way Zhechev positively reinvented a manufactured archaic tradition as a mainstay of primeval wisdom and mysticism offers an interesting testimony to the quest for 
a concept of "integral traditionalism" in a form that was reconcilable with the progressism of the Zhivkov era.

Keywords: conservatism, Toncho Zhechev, The Spring of the White-Legged Girl, the immured woman, traditionalism, Communism

\section{Notka o autorze}

Grażyna Szwat-Gyłybowa (gszwat@ispan.waw.pl) - slawistka, historyk literatury i kultury, profesor nadzwyczajna w Instytucie Slawistyki Polskiej Akademii Nauk, wykładowczyni literatur i kultur południowosłowiańskich na Uniwersytecie Warszawskim (1981-2013). Autorka książek: W kręgu butgarskiej groteski (o twórczości Jordana Radiczkowa) (1991), Haeresis bulgarica w bułgarskiej świadomości kulturowej XIX i XX wieku (2005), współautorka Leksykonu tradycji bułgarskiej (2011). Zainteresowania naukowe: historia kultur południowosłowiańskich, historia idei na Bałkanach, historia ruchów religijnych, polityka pamięci.

Grażyna Szwat-Gyłybowa, PhD (gszwat@ispan.waw.pl) - Slavist, historian of literature and culture; Associate Professor at the Institute of Slavic Studies, Polish Academy of Sciences, lecturer in South-Slavic literatures and cultures at the University of Warsaw (1981-2013). Author of the books: W kregu butgarskiej groteski (o twórczości Jordana Radiczkowa) (1991), Haeresis bulgarica w bułgarskiej świadomości kulturowej XIX i XX wieku (2005), Leksykon tradycji bułgarskiej (co-authored, 2011). Research interests: history of South-Slavic cultures, history of ideas in the Balkans, history of religious movements, politics of memory and remembrance. 